\title{
An Archaeological Survey of a Pipeline Route Near Sabine Pass, Jefferson County, Texas
}

Kenneth M. Brown

Follow this and additional works at: https://scholarworks.sfasu.edu/ita

Part of the American Material Culture Commons, Archaeological Anthropology Commons, Environmental Studies Commons, Other American Studies Commons, Other Arts and Humanities Commons, Other History of Art, Architecture, and Archaeology Commons, and the United States History Commons

Tell us how this article helped you.

This Article is brought to you for free and open access by the Center for Regional Heritage Research at SFA ScholarWorks. It has been accepted for inclusion in Index of Texas Archaeology: Open Access Gray Literature from the Lone Star State by an authorized editor of SFA ScholarWorks. For more information, please contact cdsscholarworks@sfasu.edu. 


\section{An Archaeological Survey of a Pipeline Route Near Sabine Pass, Jefferson County, Texas}

\section{Creative Commons License}

\section{(c) (1) \&}

This work is licensed under a Creative Commons Attribution-NonCommercial 4.0 International License 
AN ARCHAEOLOGICAL SURVEY OF A PIPELINE ROUTE

NEAR SABINE PASS, JEFFERSON COUNTY, TEXAS

Kenneth M. Brown

Center for Archaeological Research

The University of Texas at San Antonio

Archaeological Survey Report, No. 93

1980 
AN ARCHAEOLOGICAL SURVEY OF A PIPELINE ROUTE

NEAR SABINE PASS, JEFFERSON COUNTY, TEXAS

Kenneth M. Brown

Center for Archaeological Research

The University of Texas at San Antonio

Archaeological Survey Report, No. 93

1980 
List of Figures. .................... . $i$ Introduction ..................... 1

Previous Archaeological Work ................. 1 Method of Search .................. 3 Comments and Recommendatons................ 3 Acknowledgment ................... 4 References cited .................. 5

\section{LIST OF FIGURES}

Figure

1. Sabine Pass Pipeline Survey. ............... 2 
Introduction

In May 1980, the Center for Archaeological Research, The University of Texas at San Antonio, carried out an archaeological survey of the proposed route of an eight-inch pipeline to be installed by the Tennessee Gas Pipeline Company. The pipeline will extend from the Scurlock 0il Company tank farm about one kilometer southwest of Sabine Pass to a landfall on the Gulf Coast at a point about six kilometers west of Texas Point (Fig. 1).

The survey was done under contract between the Center for Archaeological Research and the Tennessee Gas Pipeline Company (Independent Contractor-Letter Agreement of May 1980). The fieldwork was carried out by Kenneth M. Brown, Research Associate, under the supervision of Dr. Thomas R. Hester, Center Director, and Jack D. Eaton, Associate Director.

The pipeline route is about $4.6 \mathrm{~km}$ long; crossing the chenier plain with a north-south orientation. The chenier plain consists of long, low sand and shell ridges, or cheniers, subparallel to the present coast, alternating with saline or brackish marsh and mudflats (Fisher et al. 1973; Kane 1959; Byrne, LeRoy, and Riley 1959). The area is also dotted with many elongate to irregular ponds. Ground visibility during the survey was fair to good on the cheniers, especially on the seaward side where the coarsest sediments were exposed; sandy deflated surfaces are common there. Washovers where the cheniers have been breached during high water also offered good visibility. The marsh between the cheniers, although dry enough during the survey to walk on in most places, is heavily vegetated, with a substrate of wet silt, clay, and organic muck. Ground visibility here was very unfavorable:

Previous Archaeological Work

The earliest archaeological work in the area was a survey carried out by Gus Arnold on the Sabine and Neches Rivers in 1940-41 for the WPA-University of Texas (notes on file, Texas Archeological Research Laboratory, Balcones Research Center, Austin). In 1972, Dessamae Lorrain surveyed Sea Rim State Park (former1y Jefferson County Beach Park), to the northwest of the present project area; 11 sites were located, al1 shel1 middens along watercourses (Lorrain 1973). From 1972 to 1974, the Texas Parks and Wild1ife Department carried out test excavations at Sabine Pass Battleground, east of the project area (Holtzapple and Roberson 1976). In 1972, the Texas Archeological Salvage Project (now the Texas Archeological Survey [TAS]) performed a survey of the Taylor's Bayou drainage, locating several prehistoric sites, again along watercourses (Aten 1972). In 1973 the TAS also did a survey of the Sabine Lake area (McGuff and Roberson 1974) and of the Louisiana Loop pipeline (Prewitt 1973). In 1977, further surveying of Sea Rim State Park resulted in an additional site located by Tom Medlin and three new sites located by Ron Ralph. A survey of Lakefront Park in Port Arthur, by Jim Warren of the Soil Conservation Service, located no sites. 


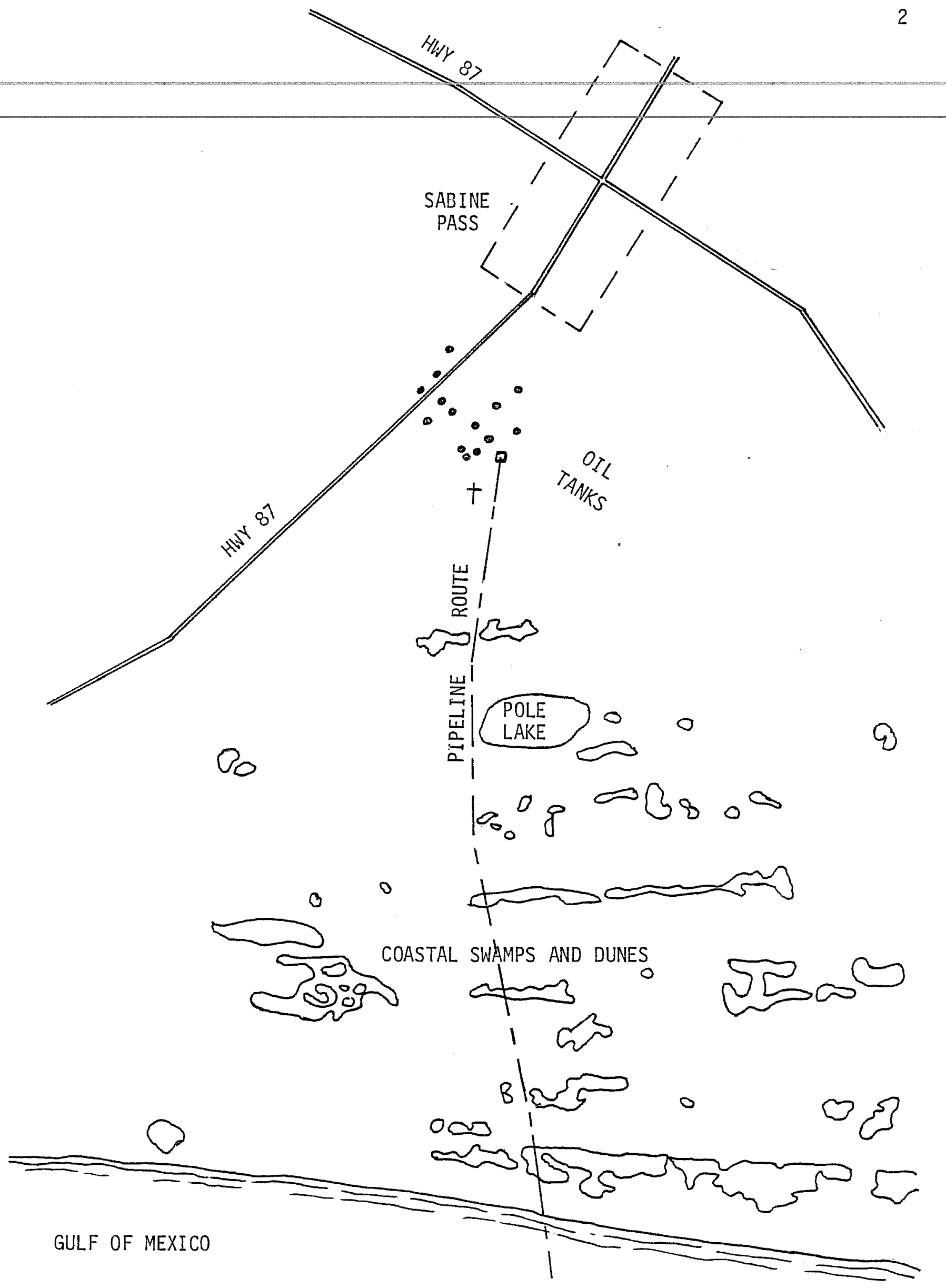

Figure 1. Sabine Pass Pipeline Survey. Shown is approximate alignment of the routing. 
Method of Search

Before the survey was begun, a file search of the site records at the Texas Archeologica1. Research Laboratory was done. No historic or prehistoric sites had been recorded in the project area. The Page Cemetery (ca. late 1840s to the present) lies just to the west of the tank farm, but will not be affected by pipeline construction.

The survey was performed on foot and by helicopter. The flight followed the staked pipeline route from the tank farm to the Gulf and return, with landings on the beach and on two cheniers that lay across the route. About 50 to 100 meters of terrain were inspected at each landing. In addition, about 1,000 meters of the largest chenier immediately south of the tank farm, and part of the marsh adjacent to it, were inspected on foot. This particular chenier may have been used as a route between Fort Manhassett (41 JF 45) and the first site of the Sabine Pass defenses during the 1860s (see Holtzapple and Roberson 1976:Fig. 14). No archaeological evidence was found except for recent historic debris, mainly bottle fragments, possibly left by waterfowl hunters.

Except for very recent storm-deposited debris, the only archaeological evidence found on the beach at the Gulf landfall was a hand-finished green glass wine bottle rim sherd, and a body sherd probably from the same bottle. The beach here was inspected carefully, since in the past significant archaeological material has been recovered from McFaddin Beach (41 JF 50) to the west (Long n.d.).

Comments and Recommendations

The chenier plain in the survey area is a relatively thin veneer of quite recent Holocene sediments (see Fisher et al.:Fig. 15, section C-D), radiocarbon dated at about 600-800 B.P. at the north end of the area and becoming progressively younger toward the coast (Gould and McFarlan 1959).*

This progradational sediment wedge, thickening toward the present Sabine River pass, overlies an older, oxidized Pleistocene surface variously termed the Prairie or Beaumont formation. The Beaumont surface, estimated at about 120-130,000 years old by Winker $(1979: 104)$, is too old to be expected to incorporate archaeological remains; however, it is possible that later Pleistocene archaeological sites might lie upon the Beaumont surface, buried by Holocene sediments. Such sites may be the source of the Paleo-Indian artifacts that have been picked up along McFaddin Beach, presumably excavated from atop the Beaumont surface offshore and washed up by storm surges. There is a wide range in the ages of the artifacts illustrated by Long (n.d.:Figs. 1-14), from early PaleoIndian (Clovis) to Poverty Point/Late Archaic. Conspicuously absent are early

\footnotetext{
*Dates are not dendrocorrected and presumably employ the 5568-year halflife. Notice should also be taken of the unusually high proportion of anomalous dates listed, which probably indicates some sort of difficulty with the kind of organic material dated.
} 
ceramic period artifacts (at least they are not mentioned by Long); this agrees with the date of 3000 to 2800 B.P. established by Gould and McFarlan as the date for the beginning of progradation. As far as can be judged from the small scale structure contour map presented by Kane (1959:Fig. 2), at least 60 to 80 feet (about 18 to $24 \mathrm{~m}$ ) of these Holocene sediments overlie the Beaumont surface in the project area. Therefore, as long as pipeline trenching does not reach 60 feet in depth, the Beaumont surface is not expected to be disturbed. However, it is still possible that Holocene archaeological remains (post-Poverty Point) may be incorporated within this sediment wedge at some higher elevation. Therefore, should archaeological remains be uncovered during trenching operations, especially in the northern portion where both historic and prehistoric remains are considered more likely to occur, an archaeologist should be notified to make an assessment.

\section{Acknowledgment}

Useful information was provided by Wayne King and Tom Stehn of the U.S. Fish and Wildlife Service, Anahuac National Wildlife Refuge, Anahuac, Texas. 


\section{REFERENCES CITED}

Aten, Lawrence E.

1972 An Assessment of the Archeological Resources to be Affected by the Taylor's Bayou Drainage and Flood Control Project, Texas. Texas Archeological Salvage Project, Research Report 7.

Byrne, John V., Duane 0. LeRoy, and Charles M. Riley

1959 The Chenier Plain and its Stratigraphy, Southwestern Louisiana. Transactions, Gulf Coast Association of Geological Societies 9: 237-259.

Fisher, W. L., L. F. Brown, Jr., J. H. McGowen, and C. G. Groat

1973 Environmental Geologic Atlas of the Texas Coastal Zone, BeaumontPort Arthur Area. Bureau of Economic Geology, The University of Texas at Austin.

Gould, H. R. and E. McFarlan, Jr.

1959 Geologic History of the Chenier Plain, Southwestern Louisiana. Transactions, Gulf Coast Association of Geologic Societies 9:261-270.

Holtzapple, T. and Wayne Roberson

1976 Sabine Pass Battleground State Historical Park, Jefferson Co., Texas, Archeological Investigations. Texas Parks and wildlife Department, Historic Sites and Restoration Branch, Archeological Report 8.

Kane, Henry E.

1959 Late Quaternary Geology of Sabine Lake and Vicinity, Texas and Louisiana. Transactions, Gulf Coast Association of Geological Societies 9:225-235.

Long, Russe11 J.

n.d. McFaddin Beach. The Pattillo Higgins Series of Natural History and Anthropology 1. Spindletop Museum, Lamar University.

Lorrain, Dessamae

1973 Archeological Potential of the Jefferson County Beach Park Site. Ms. on file, Texas Archeological Research Laboratory and Texas Parks and Wildiife Department. 
McGuff, PauT R. and Wayne Roberson

1974. Lower Sabine and Neches Rivers, Texas and Louisiana: A Study of the Prehistoric and Historic Resources in Areas Under Investigation for Navigation Improvement. Texas Archeological Survey, Research Report 46.

Prewitt, E1ton R.

1973 An Archeological Reconnaissance of the Areas to be Affected by the Proposed Louisiana Loop Pipeline, Cameron Parish, Louisiana, Jefferson and Liberty Counties, Texas. The University of Texas at Austin, Research Report 25.

Winker, Charles D.

1979 Late Pleistocene Fluvial-Deltaic Deposition, Texas Coastal Plain and Shelf. M.S. Thesis, Department of Geology, The University of Texas at Austin. 